\title{
COMMON RAVENS NESTING IN WINNIPEG, MB
}

TOM REAUME, 212 Sherburn St., Winnipeg, MB R3G 2K6

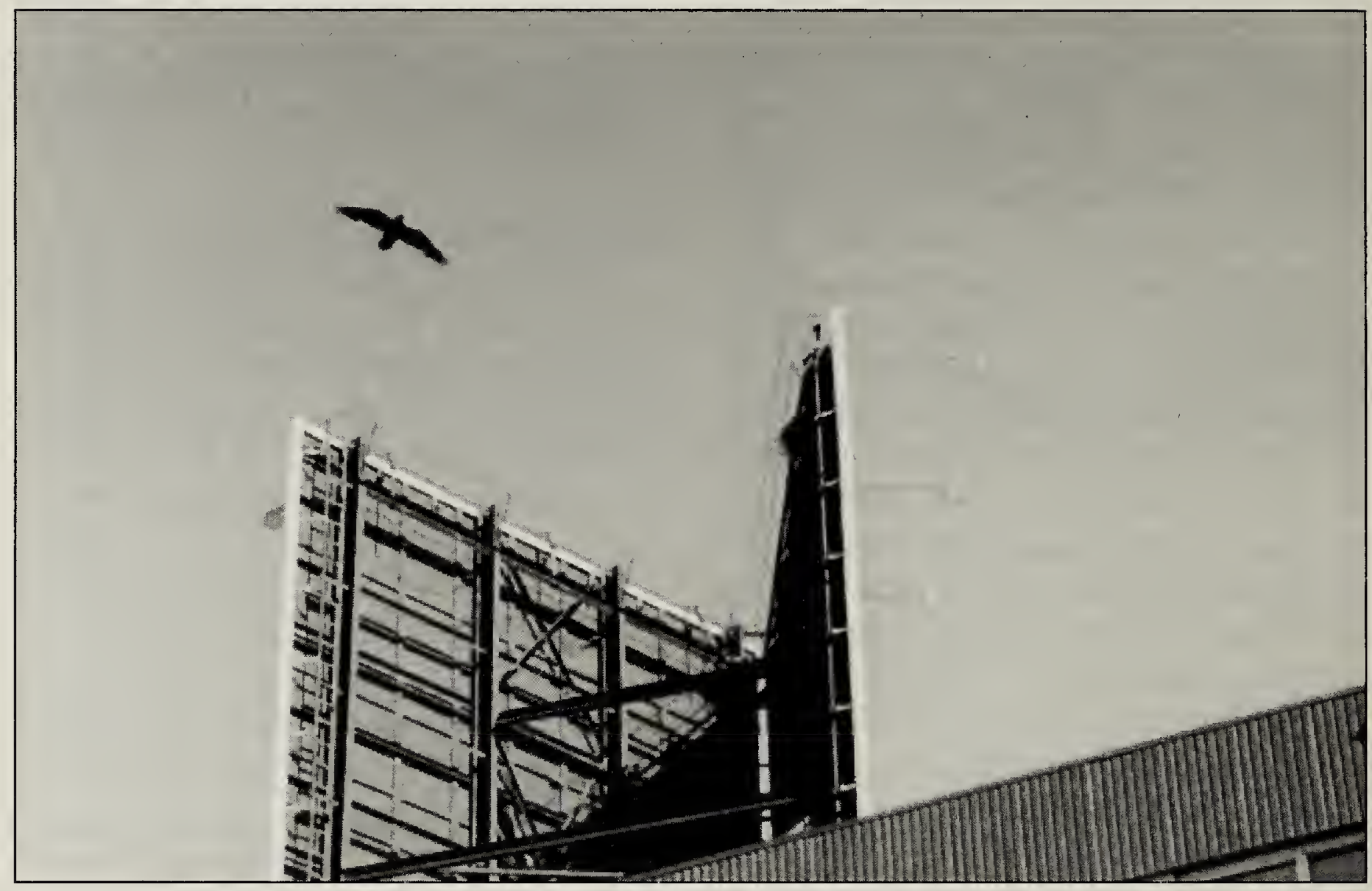

Figure 1. Raven flying near nest at top of right (eastern) side of $V$-shaped billboard facing Portage Avenue in Winnipeg, 16 May 2005.

Tom Reaume

American Crows have been nesting in Canadian cities for decades but Common Ravens, the largest members of the Corvidae, are now only beginning to nest within the city of Winnipeg (pop. 668,000). There are previous reports of ravens attempting to nest in the downtown area of Winnipeg, but no specific locations are provided..$^{1}$ This is the first published account of a successful raven's nest within the city.

Casual observations in March of flying adult ravens, carrying bare deciduous branches/twigs in their bills led to locating two nests: one in 2005 and another in 2006. Each nest was built within a $V$-shaped advertising billboard (Figures 1 and 2) situated atop 3- or 4-storey, flat-topped, occupied commercial buildings along the south side of the 8-laned Portage Avenue. In both cases, the nest was toward the back of the wide part of the $V$ and built near the top of a walkway of metal grating. This made the woven deciduous branches/twigs easy to locate through binoculars from the ground. The narrow, northern end of the $\checkmark$ faced Portage Avenue.

The 2005 nest was located on a billboard at 570 Portage, at Langside Street (Figure 1). This nest was unsuccessful. Eggs may have been laid, but no young were observed in the nest. The 2006 nest was located on a billboard farther west, at 960 Portage Avenue at Lipton Street (Figure 2). This 


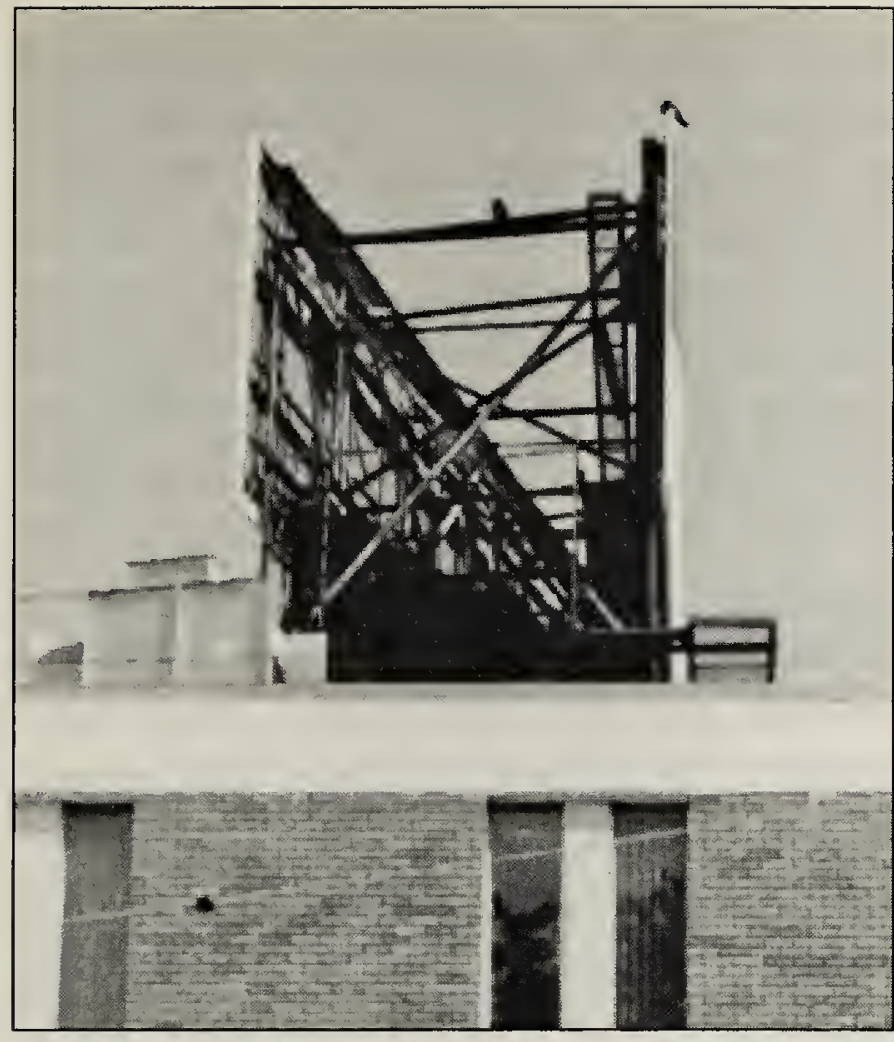

Figure 2. Two raven fledglings perched on V-shaped billboard on 22 May, 2006. The nest is near the top on the left (western) side.

Tom Reaume

nest was successful. Six eggs were laid and five hatched (Viacom employee, pers. comm., April 2006). I observed three young ravens leaving this nest.

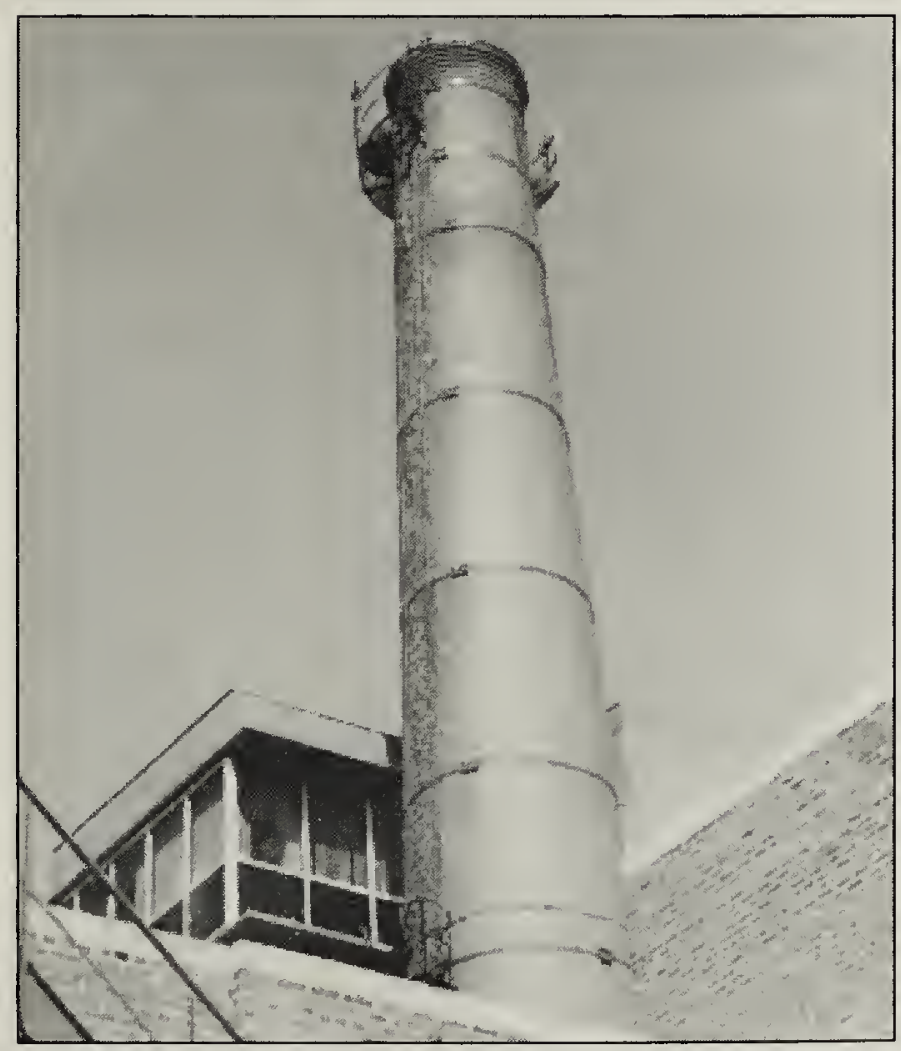

Figure 3. Nest of raven on metal walkway near top of a $37 \mathrm{~m}$ tall chimney at Deer Lodge Centre, Winnipeg, 22 May 2006

Tom Reaume
A partial chronology of this successful nest in 2006 is as follows. On 19 April, the advertisement on the west (nesting) side of the billboard was changed. The pair of adults did not abandon their nest since it probably contained newly-hatched nestlings. On 2 May, begging calls by nestlings were heard when a parent arrived with food. The begging calls of young Common Ravens are audibly lower that those of American Crow nestlings. On 5 May, three darkly-feathered heads of nestlings were visible in the nest when an adult arrived with food. On 9 May, one dark nestling, with well-developed primary (wing) feathers, was perched on the southern rim of the nest. Its continuously open bill revealed a pink lining as it tried to keep cool in the noonday sun and $20^{\circ} \mathrm{C}$ temperature. On 18 May, in the late afternoon, two young ravens were perched at the southern end of the metal walkway several metres south of the nest. The third young remained in the nest. On 22 May, in the morning, two fledglings were perched on connecting steel beams between the two billboards (Figure 2). By $1400 \mathrm{~h}$, one young had flown down to the flat roof west of, and supporting, the billboard. Soon a second young raven dropped about 5 $\mathrm{m}$ to join the first young on the roof. On 4 June, in the morning, two young ravens were on separate rooftops within one block of the nest. The third young fed on a lawn. I approached it on foot to about $5 \mathrm{~m}$ before it flew to the roof of a home.

A second raven's nest was located in 2006 from directions provided by a friendly visitor at the billboard nest I was watching. This second nest was farther west, at 1209 Portage, at Woodlawn Street. It was built on the southern side of a metal walkway near the top of a 37 $\mathrm{m}$ tall chimney associated with the Deer Lodge Centre (Fig. 3). This nest was 
unsuccessful. In 2005, a nest was built on the northern side of the same walkway. It also was unsuccessful (Tab Harrop, pers. comm., 12 June 2006).

It was interesting to observe that the presence of Common Ravens appeared to deter Rock Pigeons from landing. However, once a billboard nest site is abandoned or its nestlings have fledged, the pigeons quickly return and begin reusing the structure for perching and roosting once again.

Post script: commercial interests seem to outweigh natural history ones when it comes to ravens nesting in Winnipeg. In October, a fake owl was placed on top of the billboard that housed the successful nest in 2006, and on a nearby billboard. In addition, the song of a distressed song bird can be heard coming from a small blue box on the first billboard.

1. MANITOBA AVIAN RESEARCH COMMITTEE. 2003. The Birds of Manitoba. Manitoba Naturalists Society, Winnipeg, Manitoba

Editor's Note: Writing in 1977, Stuart Houston noted "Prior to 1875 , ravens were present throughout the breeding season across the present prairie provinces, extending down into the Dakotas" (Blue Jay 35, p. 149), but they disappeared from the prairies with the demise of the bison. Urban Winnipeg seems to be one of the final frontiers in the raven's reoccupation of former range in southern Manitoba. This process began with the appearance of wintering birds in the southeast in the 1930 s and the province's first nest record in what is now Whiteshell Provincial Park in 1942 (The Birds of Manitoba). Extension of the breeding range beyond the southeastern boreal forest began in earnest around 1990 . Near Winnipeg, nesting was recorded at Oak Hammock Marsh in 1994 and southwest of Oak Bluff in 1997 (R.F. Koes). Jack Dubois observed a nest, apparently unsuccessful, on a railway bridge near downtown Winnipeg in or around the year 2000. A sighting of juvenile ravens at the University of Manitoba campus in 2005 suggested successful nesting nearby (P. Taylor); perhaps other records will come to light following publication of this article.

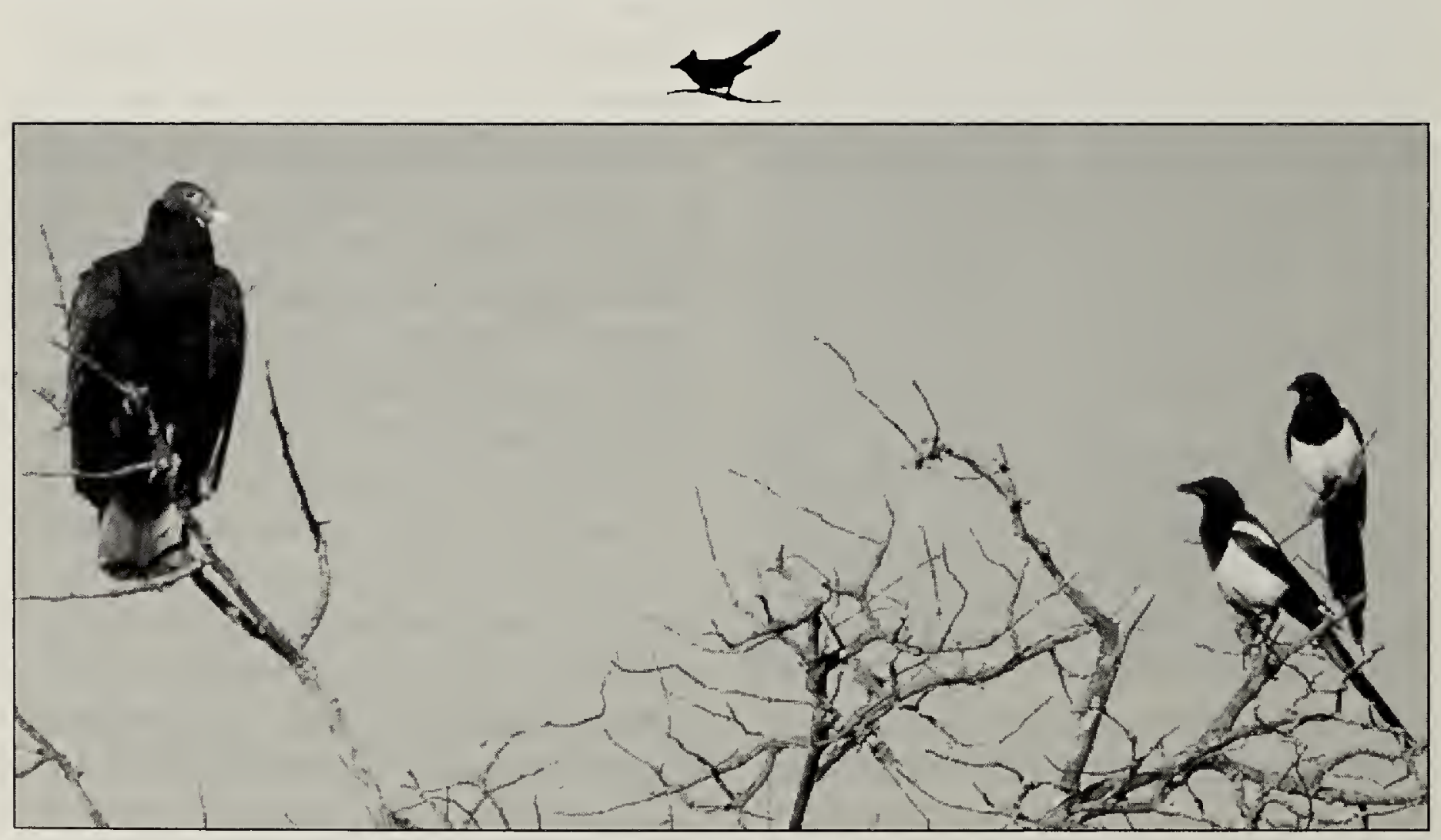

Turkey Vulture with two of three Black-billed Magpies in the same tree, $20 \mathrm{~km}$ nw of Saskatoon, September 29, 2006.

George Tosh 